\title{
ASPEN RECRUITMENT AND StAND STRUCTURE IN THE Gallatin ElK Winter Range OF SoUTHWeSt MONTANA
}

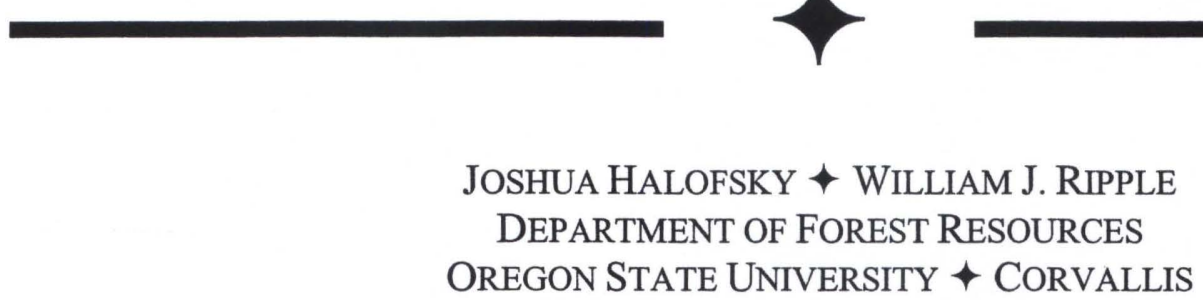

\section{$\uparrow \quad$ ABSTRACT}

This study examines the relationship between wolf, elk, and aspen within the framework of trophic cascades inside and outside of the Gallatin elk winter range. The overall goal of this study is to determine if an association exists between aspen recruitment, and historic and current elk browsing activities as affected by the absence or presence of wolf predation. This study also examines if other factors (climate fluctuations, conifer invasion, fire suppression) may have had a role in aspen decline. Through the examination of current and historic elk browsing levels, current and historic browsing effects on aspen recruitment are addressed. Potential historic browsing affects were assessed with tree rings, aspen age structures, historic documents, and an elk exclosure erected in 1945. Current browsing levels were assessed through plant architecture methods and elk pellet counts. Initial results indicate that a gap in aspen recruitment is present yet aspen have successfully recruited inside an elk exclosure located within the same elk winter range. The lack of recruitment outside the exclosure appears to be due to chronic elk herbivory, although other factors need further evaluation. Future results will elucidate if the recruitment gap occurred after wolf extirpation in the 1920's.

\section{INTRODUCTION}

Scientists are currently concerned with the lack of aspen (Populus tremuloides) recruitment in the western United States (Romme et al. 1995, YNP 1997, NRC 2002). Aspen decline has been variously attributed to fire suppression, natural stand dynamics, climate fluctuations, climate change, and browsing (Houston 1973, Loope and Gruell 1973, Romme et al. 1995, YNP 1997, Meagher and Houston 1998, Singer et al. 1998). However, few studies have investigated the relationship between top predators and the regeneration of this tree species. The historic extirpation and recent reintroduction of the gray wolf (Canis lupus) into the Greater Yellowstone Ecosystem (GYE) provides investigators with a unique opportunity to study the effects of a top predator on ecosystem dynamics, and more specifically, aspen regeneration.

Aspen largely reproduce vegetatively (Jones and DeByle 1985), producing genetically identical stems known as ramets. Some investigators have therefore concluded that some aspen stands, composed of clones, can be thousands of years old (Barnes 1975, Mitton and Grant 1996). Aspen can also reproduce by establishment from seeds, but such events in the GYA are quite rare due to the historical 
suppression of fires (Romme et al. 1995). Even when a fire does occur, McDonough (1985) notes that exacting conditions are necessary for germination to be successful such as an extended period of relatively high soil moisture and the presence of a mineral soil bed. Therefore, because seeding is a rare event and the majority of aspen have not vegetatively reproduced, concern exists that once the mature aspen are gone, they will not be easily replaced. Thus, due to its widespread decline in GYE, understanding both the historic conditions and the processes leading to the current aspen decline is therefore important to enhance its potential survival.

Despite studies illustrating that browsing can inhibit aspen regeneration, few studies have directly investigated the effects of ungulate browsing behavior on aspen dynamics (Fortin et al. 2005). In addition to ungulate affects on plants, it is also probable that the presence of a large carnivores can influence both ungulate population size and behavior, and in doing so, affect aspen population dynamics (White et al. 1998, Ripple and Larsen 2000, Mao 2003, Binkley et al. in press). The ability of a single species to exert strong direct and indirect influences on other trophic levels is central to the theory of trophic cascades. In the GYE, it is possible that the extirpation of the gray wolf (Canis lupus) in the 1920's has lead to changes to both elk browsing behavior and elk density, thus impacting aspen recruitment (Ripple and Larsen 2000, Larsen and Ripple 2003). Therefore, the objective of the study was to examine historic aspen recruitment within the framework of trophic cascades theory in the Gallatin elk winter range. The a priori hypothesis of this study was that the decline and extirpation of the gray wolf in the 1920's resulted in increased elk herbivory and a subsequent decline in aspen recruitment and change in aspen stand structure.

\section{$\downarrow \quad$ STUDY AREA}

The Gallatin is the main wintering area of the Gallatin elk herd (Lovaas 1970). Elevation ranges between $2400-3000 \mathrm{~m}$. Heavy, deep snows in the fall and winter force the elk herd to move to lower elevations that include both the Daly Creek and Black Butte watersheds, the core area of the elk winter range (Lovaas 1970). In the current study, all aspen stands within the Daly Creek and the northern half of the Black Butte watersheds were examined (Figure 1).

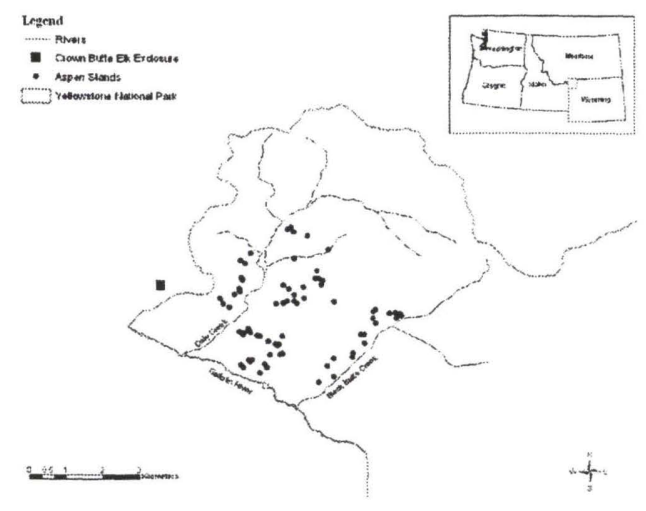

Figure 1: Study Area

\section{$\downarrow \quad$ METHODS}

An enumeration of all aspen stands was completed with 1:24,000 scale aerial photography and field reconnaissance. A stand was defined as containing a minimum of three aspen stems less than $30 \mathrm{~m}$ away from each other. The $30 \mathrm{~m}$ distance was measured from stand edge to stand edge using a laser range finder. Within each stand, broad site characteristics (xeric, mesic, riparian) were noted. Diameter at breast height (DBH) measurements and increment cores were also obtained at $\sim 1.5 \mathrm{~m}$ above the ground. Up to three increment cores and DBH measurements were taken, if available, in each of three DBH classes: 5 to $<10 \mathrm{~cm}, 10$ to $>20 \mathrm{~cm}$, and $>20 \mathrm{~cm}$ for a possible total of 9 cores. Due to missing age classes and heart rot in older trees, three cores were not always collected from each age class in a given stand. In such cases, nine DBH measurements were recorded from trees in the DBH classes found within the particular stand. When possible, additional cores at $0.2 \mathrm{~m}$ above the ground were also collected. By comparing $1.5 \mathrm{~m}$ cores with cores collected at $0.2 \mathrm{~m}$, the time required for a stem to grow from 0.2 to $1.5 \mathrm{~m}$ was approximated.

A $2 \times 20 \mathrm{~m}$ belt transect was established in every third aspen stand to examine current aspen reproduction levels. The belt transect was run from the stand edge to the stand centroid. The direction of the belt transect was randomly chosen with a random number table. Within each transect, aspen ramet information was collected. Aspen ramets were defined as immature aspen less than $200 \mathrm{~cm}$ in height. Total number, ramet height, and previous year browsing (yes/no) were recorded. DBH information was also recorded for aspen saplings, defined as aspen greater than $200 \mathrm{~m}$ in height and less than $5 \mathrm{~cm}$ in DBH. Current conifer invasion was studied by 
collecting aspen and conifer basal area information using a basal area gauge with a basal area factor of 5 . Aspen and conifer basal area were summed together to create a total stand basal area. The total stand basal area was divided by conifer basal area to determine the proportion of stand basal area that was conifer. A regression of aspen ramet density and conifer basal area was conducted to ascertain the relationship between the two variables. Fire information was determined by the presence and absence of fire scars on Douglas fir (Pseudotsuga menziesi) and from historic documents.

Within the same elk winter range, additional data on aspen was collected within a large fenced elk exclosure erected in 1945. DBH measurements were collected on all aspen stems greater than $5 \mathrm{~cm}$ in DBH. Cores were extracted from up to three trees for each $1 \mathrm{~cm}$ increase in DBH. Those trees cored at breast height were also cored at $0.2 \mathrm{~m}$ from the tree base.

All cores were stored in propylene straws, air-dried, mounted, and sanded. Rings will be counted using a dissecting microscope and standard dendrological procedures. To examine climate, Palmer Drought Severity Index (PDSI) was downloaded from the International Tree Ring Databank (ITRDB) website. Average PDSI values are centered around the value zero. Drier conditions are reflected in more negative values. Two master chronologies will also be downloaded from the ITRDB website as another climate measure. Lastly, annual stream discharge within the watershed will also be examined as a third line of long-term climate trends and fluctuations.

\section{$\downarrow$ PROGRESS REPORT}

Because data from the previous field season are still being analyzed, only some of the results are included. Data analysis will continue and be completed in 2006. All aspen stands $(n=71)$ within the study area were enumerated and their respective locations were recorded with a global positioning system. DBH information was collected on every aspen tree found $(n=462)$ within the study area. No aspen smaller than $17 \mathrm{~cm}$ in DBH was located in the study area. DBH information was also collected inside an elk exclosure situated within the same winter range. 183 saplings were measured inside the exclosure with DBH's ranging from $1 \mathrm{~cm}$ to $43 \mathrm{~cm}$ (Table 1). Ring analyses have not been conducted so an age-diameter relationship has not yet been created.
Table 1: Aspen number inside and outside of the elk exclosure for a given DBH class.

\begin{tabular}{|c|c|c|}
\hline \hline DBH Class (cm) & Inside Exclosure & Outside Exclosure \\
\hline \hline $5-\geq 10$ & 94 & 0 \\
\hline \hline $10-\geq 20$ & 73 & 11 \\
\hline \hline$\leq 20$ & 16 & 451 \\
\hline
\end{tabular}

Of the 262 ramets studied in the various belt transects, no ramet was over $1 \mathrm{~m}$ tall and $>90 \%$ of all ramets had been browsed the previous winter. No strong association between conifer invasion and ramet density was observed (Figure 2). No long-term PDSI trend was found (Figure 3).

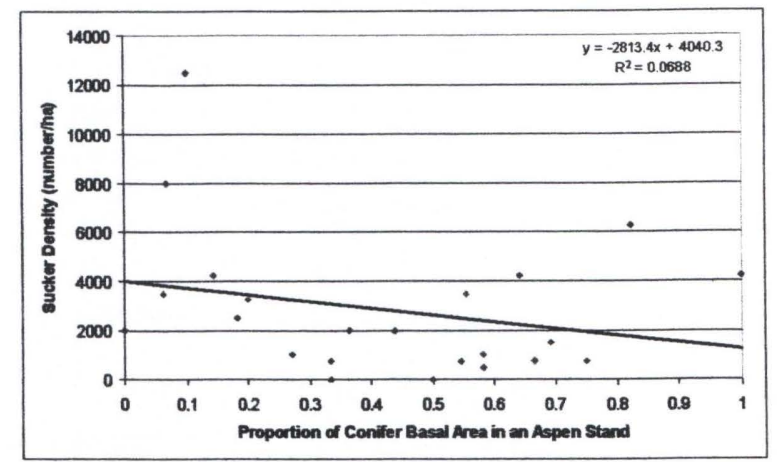

Figure 2: Relationship between aspen ramet density (current recruitment) and the amount of conifer basal area in a stand.

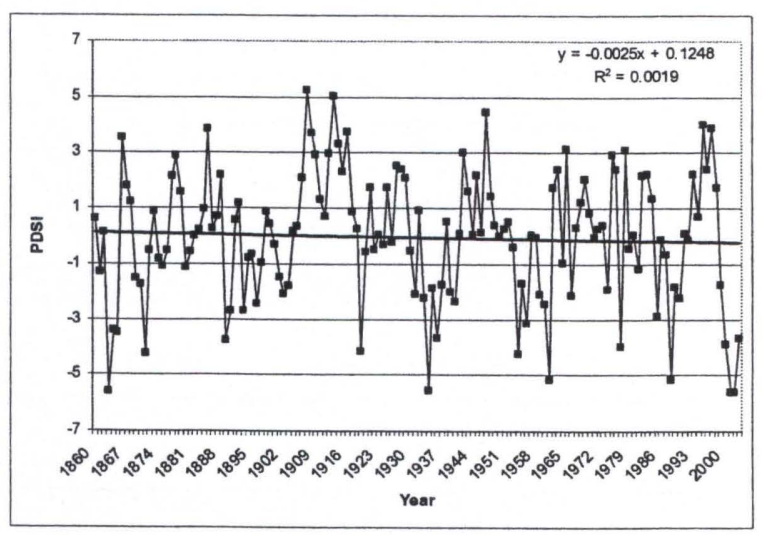

Figure 3: The Palmer Drought Severity Index (PDSI), a long-term climate record.

Initial results do indicate that there is a gap in aspen diameters in the Gallatin elk winter range suggesting that an aspen recruitment gap is present. However, within the elk exclosure located in the same elk winter range, only a small potential gap was found and DBH values for all three age classes were 
present. Fires have been absent from the study area for at least century. PDSI records do not indicate any long-term warming trend although climate fluctuations still need to be examined as do other climate indicators (master chronologies and peak flow records). No clear association between ramet densities and the amount of conifer basal area was observed. It therefore does not appear that a relationship between aspen recruitment and climate trends, fire, and conifer invasion are present. Herbivory appears to be limiting current aspen recruitment as illustrated by the high ramet browsing. The full compliment of age classes only present in the elk exclosure is suggestive of herbivory also influencing historic aspen recruitment. However, until the aspen age-diameter relationship is created, it is not possible to ascertain if an association between aspen decline and an increase in elk herbivory due the extirpation the wolf is present.

\section{$\downarrow$ Literature Cited}

Barnes, B. V. 1975. Phenotypic variation of trembling aspen in Western North America. Forest Science 22:319-328.

Binkley, D., Moore, M. M., Romme, W.H., and P. M. Brown. In press. Was Aldo Leopold right about the Kaibab deer herd? Ecosystems.

Fortin, D., L.B. Hawthorne, M.S. Boyce, D.W. Smith, T. Duchesne, and J.S. Mao. 2005. Wolves influence elk movements: Behavior shapes a trophic cascade in Yellowstone National Park. 2005. Ecology 86(5): 13201330.

Houston, D. B. 1982. The Northern Yellowstone elk, ecology, and management. New York, Macmillan.

Jones, J. R., and N. V. DeByle. 1985. Climate. Pages 57-64 in N. V. a. R. P. W. DeByle, editor. Aspen: ecology and management in the western United States. U.S. Forest Service General Technical Report RM-119

Larsen, E. J. and W. J. Ripple. 2003. Aspen age structure in the northern Yellowstone ecosystem: USA. Forest Ecology and Management 179: 469-482.
Loope, L.L., and G.E. Gruell. 1973. The ecological role of fire in the Jackson Hole area, northwestern Wyoming. Quaternary Research 3:425-443.

Lovaas, A.L. 1970. People and the Gallatin elk herd. Montana Fish and Game Department, Helena, Montana, 44 pp.

Mao, J.S., 2003. Habitat Selection by Elk before and after Wolf Reintroduction in Yellowstone National Park, Wyoming. M.S. Thesis, University of Alberta, Edmonton, Alberta, $51 \mathrm{pp}$.

Meagher, M. M., and D. B. Houston. 1998. Yellowstone and the biology of time. Oklahoma State University Press, Norman, OK.

McDonough, W. T. 1985. Sexual reproduction, seeds, and seedlings. Aspen: ecology and management in the Western United States. N. V. DeByle, R.P. Winokur, and P. Robert. Fort Collins, CO, General Technical Report RM-119. U.S. Department of Agriculture, Forest Service, Rocky Mountain Forest and Range Experiment Station: 25-28

Mitton, B. J., and M. C. Grant. 1996. Genetic variation and the natural history of quaking aspen. Bioscience 46:25-31

National Research Council. [NRC] 2002. Ecological dynamics on Yellowstone's northern range. National Academy Press, Washington, D.C.

Ripple, W. J., and E. J. Larsen. 2000. Historic aspen recruitment, elk, and wolves in northern Yellowstone National Park, USA. Biological Conservation 95:361-370

Romme, W. H., Turner, M. G., Wallace, L. L., and Walker, J. S. 1995. Aspen, elk, and fire in northern range of Yellowstone National Park. Ecology 76:2097-2106.

Singer, F. J., Zeigenfuss, L. C., Cates, R. G., and D.T. Barnett. 1998. Elk, multiple factors, and persistence of willows in national parks. Wildlife Society Bulletin 26:419-428. 
White, C. A., Olmsted, C. E., and C. E. Kay. 1998. Aspen, elk, and fire in the Rocky Mountain national parks of North America. Wildlife Society Bulletin 26:449-462

Yellowstone National Park, [YNP] 1997. Yellowstone's northern range: complexity and change in a wildland ecosystem. U.S. Dept. of Interior, Yellowstone National Park, Mammoth Hot Springs, Wyoming. 